\title{
Host Status of Graminaceous Cover Crops for Pratylenchus brachyurus
}

\author{
M. M. Inomoto, Departamento de Fitopatologia e Nematologia, Escola Superior de Agricultura Luiz de Queiroz, \\ Universidade de São Paulo, CP. 9, São Paulo, Brazil; and G. L. Asmus, Laboratório de Nematologia, Embrapa Ag- \\ ropecuária Oeste, CP. 661, Mato Grosso do Sul, Brazil
}

\begin{abstract}
Inomoto, M. M., and Asmus, G. L. 2010. Host status of graminaceous cover crops for Pratylenchus brachyurus. Plant Dis. 94:1022-1025.

Taking into account that information about the host status of cover crops for Pratylenchus brachyurus is scarce or contradictory, this study was undertaken to assess the host status of selected graminaceous cover crops by estimating nematode reproduction and their ability to decrease the nematode density in glasshouse conditions. Furthermore, the reproductive fitness of three $P$. brachyurus populations was assessed for Brachiaria grasses. Silage and forage sorghum proved to be good hosts for P. brachyurus; consequently, they should be avoided in fields infested with this lesion nematode, mainly before susceptible crop such as soybean, common bean, cowpea, and cotton. Dictyoneura grass, the pearl millet cv. ADR 300, and black oat were poor hosts for P. brachyurus but may increase densities of this nematode over time. Consequently, these cover crops might be used in infested fields for only short periods, because they could increase the $P$. brachyurus population density slowly but progressively.
\end{abstract}

The lesion nematode Pratylenchus brachyurus (Godfrey) is widespread in soybean (Glycine max (L.)), common bean (Phaseolus vulgaris L.), cowpea (Vigna unguiculata (L.)), and cotton (Gossypium hirsutum L.) fields in Brazil, and frequently causes crop losses, mainly under no-tillage system $(3,20,21)$. The use of autumn or winter cover crops, commonly planted in croplands under no tillage, may affect the soil density of plant-parasitic nematodes, sometimes causing the build up of polyphagous species (4), such as Pratylenchus brachyurus. The management of $P$. brachyurus in a no-tillage system would be set by choosing cover crops that decrease nematode density and avoiding the ones that increase it. However, information about the host status of cover crops for this lesion nematode is scarce or contradictory. For example, black oat (Avena strigosa Schreb.) was tested only once for $P$. brachyurus reproduction (8). Sorghum (Sorghum bicolor (L.)) was rated as a poor host for P. brachyurus by Endo (2) but as a good host for the same nematode by Sharma and Medeiros (19). Such variation may be caused by the different $P$. brachyurus populations or experimental methodologies used in these trials.

In addition, the reproduction of $P$. brachyurus usually has been evaluated in short-term experiments (8 to 10 weeks

Corresponding author: M. M. Inomoto
E-mail: mminomot@esalq.usp.br

Accepted for publication 17 April 2010.

doi:10.1094/PDIS-94-8-1022

(c) 2010 The American Phytopathological Society between inoculation and nematode extraction) but Machado et al. (12), studying the host status of green manures for P. brachyurus, hypothesized that longer periods could be necessary to achieve reliable nematode density increase. This study was undertaken to assess the host status of selected graminaceous cover crops to $P$. brachyurus by estimating nematode reproduction at least 13 weeks after inoculation and to evaluate their usefulness in decreasing nematode density. Furthermore, the reproductive fitness of three $P$. brachyurus populations was assessed for Brachiaria grasses.

\section{MATERIALS AND METHODS}

Three glasshouse experiments were conducted at the Escola Superior de Agricultura Luiz de Queiroz (ESALQ), Piracicaba, Brazil $\left(22^{\circ} 43^{\prime} 9^{\prime \prime} \mathrm{S}\right.$ and $\left.47^{\circ} 36^{\prime} 59^{\prime \prime} \mathrm{W}\right)$. The tested plants were grown in $500-\mathrm{cm}^{3}$ plastic pots (three per pot) containing 450 $\mathrm{cm}^{3}$ of an autoclaved soil $(76 \%$ sand, $6 \%$ silt, $18 \%$ clay, $1 \%$ organic matter content, and $\mathrm{pH}$ 5.9). The objective of experiment 1 was to evaluate the host status of some graminaceous cover crops for P. brachyurus. The objectives of experiment 2 were to evaluate the host status of Brachiaria grasses for $P$. brachyurus and the reproductive fitness of three populations of $P$. brachyurus on Brachiaria grasses. Experiment 3 was conducted to confirm the results of experiments 1 and 2 for selected graminaceous cover crops, assessing the reproduction of $P$. brachyurus in both cover crops and soybean, a crop that would be planted following the cover crops.

Nematode collections. Three $P$. brachyurus populations, designated $\mathrm{Pb}_{20}, \mathrm{~Pb}_{21}$, and $\mathrm{Pb}_{22}$, were used in the experiments.
One single female extracted from okra roots (Abelmoschus esculentus (L.)) cultivated in Seropédica, Rio de Janeiro state, was used to initiate the population $\mathrm{Pb}_{20}$, which was maintained on alfalfa callus in the laboratory (16) as well as on okra roots in the glasshouse. The two other populations were collected from cotton field soils from Serra do Ramalho, Bahia state $\left(\mathrm{Pb}_{21}\right)$ and Campo Verde, Mato Grosso state $\left(\mathrm{Pb}_{22}\right)$. These soils were potted, and maize (Zea mays L.) was grown during 2 months so as to increase the nematode population densities. After that, nematodes were extracted from maize roots by blender and centrifugal flotation (1). To start the cultures, females were picked up under a stereomicroscope and inoculated on okra plants growing in sterilized soil. Eight clay pots with okra plants received 30 to 65 females per pot and were maintained in the glasshouse. Specimens of each of the three populations were periodically extracted from okra roots and checked under a light microscope to confirm the species identity based on morphological features (5). In addition, the molecular diagnosis of the populations was confirmed by Machado et al. (11) using a species-specific reverse primer. The inoculum was an aqueous suspension, containing 135 juveniles and females per milliliter, which was obtained from okra roots by a modified Baermann method (6).

Experiment 1. Only population $\mathrm{Pb}_{20}$ was used in this experiment, and 14 cover crops were tested: black oat (cv. IPFA 99006), two forage sorghum cultivars ( $S$. bicolor cvs. IPA 7301011 and Santa Eliza), three silage sorghum hybrids (BR 601, BR 700, and BR 701), a forage sorghumsudangrass hybrid $(S$. bicolor $\times S$. sudanense (Piper): BR 800), four pearl millet cultivars (Pennisetum glaucum (L.) cvs. ADR 300, ADR 500, BN 2, and BRS 1501), Kennedy ruzi grass (Brachiaria ruziziensis Germain \& Evrard), Mulato grass $(B$. ruziziensis $\times B$. brizantha (Hochstetter ex A. Rich.)), and prosomillet (Panicum miliaceum L.). Soybean cv. Pintado and showy crotalaria (Crotalaria spectabilis Roth) were included as good and poor host standards, respectively $(12,18)$. Seed of each cover crop and standard hosts were sowed directly in six plastic pots, corresponding to six replicates. Due to the different periods needed for germination and root growth, the plants were not sown at the same date: showy crotalaria was planted first, followed by 
the Brachiaria grasses and pearl millet cultivars, soybean and sorghum, and, finally, black oat. Three days after the germination, the plants were thinned to three per pot. Two weeks after thinning, $2 \mathrm{ml}$ of the nematode suspension was distributed into two holes, 2 and $4 \mathrm{~cm}$ in depth, made in the soil, close to the plant stem. Therefore, the initial population density (Pi) of Pratylenchus brachyurus was 270. The plants were initially maintained in a shaded room for 2 days to avoid heat stress on the nematode and then transferred to the glasshouse. The final population density (Pf) of $P$. brachyurus was evaluated 13 weeks after inoculation, a period considered sufficient to permit a good reproduction of the nematode (12). During this period (from December to March, corresponding to spring and summer in Brazil), the soil temperatures averaged $22.5^{\circ} \mathrm{C}$ minimum and $35.4^{\circ} \mathrm{C}$ maximum. At the time of evaluation, pots were individually immersed in 4 liters of water in a container in order to separate roots from soil. Roots were washed with tap water, dried on absorbent paper, cut in $1-\mathrm{cm}$ pieces, and weighed; nematodes were extracted from a 10-g subsample (1). The entire soil of each pot was processed by a centrifugal flotation technique (9). The Pf was estimated by counting eggs, juveniles, and females from the roots, and juveniles and females from the soil. Thereafter, two nematode reproduction data (reproductive factor $[\mathrm{RF}]=\mathrm{Pf} / \mathrm{Pi}$ and Nem/g = nematode number per gram of fresh root) were calculated for each replicate.

Experiment 2. Three $P$. brachyurus populations $\left(\mathrm{Pb}_{20}, \mathrm{~Pb}_{21}\right.$, and $\left.\mathrm{Pb}_{22}\right)$ were evaluated for reproductive fitness in Brachiaria grasses in the experiment. The Brachiaria spp. tested were Kennedy ruzi grass, palisade grass (B. brizantha), creeping signal grass (B. humidicola (Rendle)), and dictyoneura grass $(B$. dictyoneura (Fig. \& De Not.)). Seed of each grass were sown directly in six plastic pots, corresponding to six replicates. Germination occurred 7 to 9 days after sowing and from 10 to 12 days after seedlings were thinned to three per pot. Twenty-two days after thinning, $2 \mathrm{ml}$ of nematode suspension was distributed into two holes, 2 and $4 \mathrm{~cm}$ in depth, made in the soil, close to the plant stems. Therefore, the Pi of $P$. brachyurus was 270 . Showy crotalaria were included as standard poor host and received the same inocula. The subsequent procedures were similar to those described for experiment 1 but the evaluation was set 15 weeks after inoculation. During this period (from October to January, corresponding to spring and summer in Brazil), the soil temperatures averaged $19.2^{\circ} \mathrm{C}$ minimum and $33.7^{\circ} \mathrm{C}$ maximum.

Experiment 3. Only population $\mathrm{Pb}_{20}$ was used in this experiment, because experiment 2 had demonstrated that its reproductive fitness for grasses was equiva- lent to $\mathrm{Pb}_{21}$ and $\mathrm{Pb}_{22}$. The plants tested were forage sorghum hybrid BR 800 , pearl millet cvs. ADR 300 and BRS 1501, and Kennedy ruzi grass, which are the graminaceous cover crops most used in Brazil $(10,15)$; the standard hosts were soybean cv. BRS 133 and showy crotalaria. Seed of each plant cultivar were sown in 14 pots and, after germination, the seedlings were thinned to three per pot and received $2 \mathrm{ml}$ of a suspension containing 270 specimens of $P$. brachyurus. Half of the pots were used for the evaluation of the Pf of $P$. brachyurus, 14 weeks after inoculation, in order to estimate the cover crops RF and $\mathrm{Nem} / \mathrm{g}$ (first evaluation). During this period (from February to June, corresponding to summer and autumn in Brazil), the soil temperatures averaged $17.9^{\circ} \mathrm{C}$ minimum and $33.9^{\circ} \mathrm{C}$ maximum. In the remaining seven pots, the shoots of the plants were cut off and one pregerminated seed of soybean cv. BRS 133 was sown in each pot. Eight weeks after sowing, nematodes were extracted from roots and soil in order to obtain the final population on soybean $($ Pf roots + Pf soil $=$ Pf soybean $)$. During the period under soybean (from June to August, corresponding to autumn and winter in Brazil), the soil temperatures averaged $12.8^{\circ} \mathrm{C}$ minimum and $31.7^{\circ} \mathrm{C}$ maximum.

Experimental design and data analysis. Experiments 1 and 3 were set up in a completely randomized design, with 16 treatments and six replicates (experiment 1), and 6 treatments and seven replicates (experiment 3). Experiment 2 was set up in a three-by-five factorial design (i.e., three $P$. brachyurus populations and five plant species) with four replicates. Data obtained (RF, Nem/g, and Pf soybean) were $\ln (x+$ 1) transformed to achieve normalization before analysis (14), which was performed by SANEST software (Departamento de Matemática e Estatística, ESALQ/USP, Piracicaba, Brazil). Thereafter, the mean values were compared by Tukey's honestly significant difference test $(P=0.01)$. The comparison among the RF of standard hosts (soybean and showy crotalaria) and the graminaceous species tested was used to characterize the host suitability of the cover crops. Cover crops with RF higher than or equal to soybean were considered good hosts for P. brachyurus. Poor hosts were those with RF equal to or lower than showy crotalaria, and moderate hosts were those with intermediate responses.

\section{RESULTS}

The highest reproduction of $P$. brachyurus in experiment 1 was obtained on the sorghum genotypes, with RF ranging from 22.3 (BR 700) to 61.1 (IPA 7301011) and $\mathrm{Nem} / \mathrm{g}$ from 191.4 (BR 700) to 978.3 (IPA 7301011) (Table 1). Proso-millet and the pearl millet cultivars were rated as poor hosts, because nematode reproduction in them was similar to showy crotalaria, with RF ranging from 0.7 (BN 2) to 2.2 (BRS 1501) and Nem/g from 7.0 (ADR 300) to 24.7 (BRS 1501). However, the Nem/g of proso-millet was higher than of showy crotalaria. Among the Brachiaria grasses, the reproduction of Kennedy ruzi grass was similar to showy crotalaria and lower than of Mulato grass but the $\mathrm{Nem} / \mathrm{g}$ from both grasses was similar and close to showy crotalaria. The RF of black oat cv. IPFA 99006 was close to showy crotalaria but the Nem/g was much higher. Such difference is due to the very low weight of oat roots (1.4 to $1.9 \mathrm{~g})$ compared with showy crotalaria (11.8 to $28.1 \mathrm{~g}$ ) or the other cover crops (e.g., pearl millet cv. ADR 300, 11.0 to 32.8). Thereafter, the RF seemed to be more reliable for evaluating $P$. brachyurus host suitability than $\mathrm{Nem} / \mathrm{g}$, and all sorghum may be rated as good hosts; Mulato grass as moderate host; and pearl millet cultivars, proso-millet, Kennedy ruzi grass, and black oat cv. IPFA 99006 as poor hosts.

Table 1. Reproductive factor $(\mathrm{RF}=$ final population density/initial population density [Pi]) of the Brazilian population $\mathrm{Pb}_{20}$ of Pratylenchus brachyurus and number of nematodes per gram of root $(\mathrm{Nem} / \mathrm{g})$ determined in the graminaceous cover crops tested 13 weeks after inoculation with $\mathrm{Pi}=270^{\mathrm{z}}$

\begin{tabular}{lcc}
\hline Treatments & $\mathbf{R F}$ & $\mathbf{N e m} / \mathbf{g}$ \\
\hline Forage sorghum IPA 7301011 & $61.1 \mathrm{a}$ & $978.3 \mathrm{a}$ \\
Forage sorghum Santa Eliza & $60.7 \mathrm{a}$ & $406.8 \mathrm{a}$ \\
Forage sorghum BR 800 & $43.1 \mathrm{ab}$ & $311.7 \mathrm{ab}$ \\
Silage sorghum BRS 701 & $41.3 \mathrm{ab}$ & $423.0 \mathrm{a}$ \\
Silage sorghum BR 601 & $36.4 \mathrm{ab}$ & $265.7 \mathrm{abc}$ \\
Soybean Pintado & $29.5 \mathrm{ab}$ & $614.6 \mathrm{a}$ \\
Silage sorghum BR 700 & $22.3 \mathrm{~b}$ & $191.4 \mathrm{abc}$ \\
Mulato grass & $8.0 \mathrm{c}$ & $72.0 \mathrm{bcd}$ \\
Proso-millet & $2.4 \mathrm{~d}$ & $62.5 \mathrm{~cd}$ \\
Pearl millet BRS 1501 & $2.2 \mathrm{de}$ & $24.7 \mathrm{ef}$ \\
Black oat IPFA 99006 & $1.2 \mathrm{de}$ & $183.5 \mathrm{bc}$ \\
Pearl millet ADR 500 & $1.1 \mathrm{de}$ & $8.0 \mathrm{ef}$ \\
Kennedy ruzi grass & $1.1 \mathrm{de}$ & $8.5 \mathrm{ef}$ \\
Pearl millet ADR 300 & $0.7 \mathrm{de}$ & $8.0 \mathrm{ef}$ \\
Pearl millet BN 2 & $0.7 \mathrm{de}$ & $7.0 \mathrm{f}$ \\
Showy crotalaria & $0.3 \mathrm{e}$ & $3.8 \mathrm{f}$ \\
\hline
\end{tabular}

${ }_{\mathrm{z}}$ Experiment 1 (experiment was not replicated, values are means of six pot-replicates). Mean followed by the same letter in a column did not differ according to Tukey's test $(P=0.01)$. 
Experiment 2 demonstrated that the four Brachiaria spp. tested exhibited different host status for P. brachyurus; with palisade grass being the most suitable and dictyoneura grass the least suitable (Table 2). Kennedy ruzi grass was close to palisade grass based on Nem/g but its RF was lower. Creeping signal grass was close to dictyoneura grass based on RF but Nem/g was higher. It was also demonstrated that $\mathrm{Pb}_{21}$ nematodes exhibit higher reproductive fitness for Brachiaria grasses than $\mathrm{Pb}_{22}$; however, the host status of Brachiaria grasses was not affected by $P$. brachyurus populations: palisade and Kennedy ruzi grasses were rated as moderate hosts and creeping signal and dictyoneura grasses as poor hosts for P. brachyurus.

Experiment 3 confirmed that sorghum hybrid BR 800 is a good host and pearl millet cv. ADR 300 a poor host for $P$. brachyurus based on the RF value (Table $3)$. In contrast to experiment 1 , the reproduction data of Kennedy ruzi grass and pearl millet cv. BRS 1501 were higher than those of showy crotalaria. Thereafter, the cover crops were rated somewhat differently from experiment 1: sorghum hybrid BR 800 as a good host for P. brachyurus, Kennedy ruzi grass and pearl millet cv. BRS 1501 as moderate hosts, and pearl millet cv. ADR 300 as a poor host. However, when soybean followed pearl millet cv. ADR 300, final populations were greater than following showy crotalaria.

\section{DISCUSSION}

A common production practice in Brazil is the "crop-pasture integration system", a variation on the no-tillage system in which a graminaceous cover crop is grown for several months (annual) or several years (perennial) between a summer cash crop such as soybean. In this system, the cover crop is sown immediately after the summer crop. The sorghum and the sorghumsudangrass genotypes we evaluated can be used as either silage or forage in an annual crop-pasture system. Therefore, as far as nematode management is concerned, depending on the host suitability of the graminaceous forage, there is a risk of increasing or at least maintaining high populations in the field. The nematode RF observed on sorghum (between 22.3 and 61.1 in experiments 1 and 3) confirmed that silage and forage sorghum are good hosts for $P$. brachyurus $(8,19)$. In addition, the results of experiment 3 demonstrated that sorghum increased densities of $P$. brachyurus in succeeding soybean plants. Therefore, silage and forage sorghum should be avoided in fields infested with $P$. brachyurus if a susceptible crop will be planted after. Sorghum is the most-studied cover crop concerning suitability for $P$. brachyurus; however, it has shown very incongruous results, perhaps due to the broad genetic diversity in this graminaceous species. Even though they belong to the same species ( $S$. bicolor), grain and silage sorghum are very different from each other. For example, grain cultivars are generally short while silage and forage cultivars are tall. Moreover, the grain sorghum cultivars are relatively poor hosts for $P$. brachyurus. Motalaote et al. (13) reported that 5 of 10 grain sorghum cultivars reduced densities of $P$. brachyurus (RF from 0.3 to 0.8 ), four marginally increased densities (RF from 1.2 to 2.1 ), and one maintained the density $(\mathrm{RF}=1)$.

Some Brachiaria grasses, mainly palisade grass and Kennedy ruzi grass, are frequently used as cover crop in classical no-tillage system and in crop-pasture integration $(10,15)$. The RF observed on Kennedy ruzi grass was comparable with that on showy crotalaria in experiment 1 but was higher in experiment 3 . Actually, this experiment demonstrated that soybean cultivated after Kennedy ruzi grass carried on a higher density of $P$. brachyurus than soybean after showy crotalaria. Additionally, among the Brachiaria grasses, dictyoneura grass should be preferred as cover crops in fields infested by P. brachyurus. Among the graminaceous cover crops tested in experiment 2, dictyoneura grass was the only one with reproduction data equivalent to that of showy crotalaria. However, it is noteworthy that densities of all $P$. brachyurus populations $\left(\mathrm{Pb}_{20}, \mathrm{~Pb}_{21}\right.$, and $\left.\mathrm{Pb}_{22}\right)$ decreased in showy crotalaria but density of $\mathrm{Pb}_{21}$, the population with the highest reproductive fitness for Brachiaria spp., was maintained in dictyoneura grass. Therefore, in view of $P$. brachyurus diversity, dictyoneura grass is probably less effective in decreasing nematode density than showy crotalaria.

The RF of $P$. brachyurus in creeping signal grass is comparable with that of dictyoneura grass but higher than that of showy crotalaria, in accordance with previous results obtained only for the $\mathrm{Pb}_{20}$ population (7). The comparable reproduction of $P$. brachyurus in both grasses is congruent with the genetic similarity between them; they differ only in their growth habit (17).

The RF of pearl millet in experiments 1 (0.7 to 2.2$)$ and 3 (1.6 to 5.0$)$ positioned this cover crop as poor or moderate host

Table 3. Reproductive factor $(\mathrm{RF}=$ final population density/initial population density [Pf/Pi] $)$ of the Brazilian population $\mathrm{Pb}_{20}$ of Pratylenchus brachyurus, number of nematodes per gram of root $(\mathrm{Nem} / \mathrm{g}) \mathrm{de}-$ termined in the graminaceous cover crops tested (first evaluation $=14$ weeks after inoculation with $\mathrm{Pi}=$ 270), and final population after soybean (Pf soybean; second evaluation $=8$ weeks after soybean sowing $)^{\mathrm{z}}$

\begin{tabular}{lccccc}
\hline & \multicolumn{2}{c}{ First evaluation (cover crops) } & & \multicolumn{2}{c}{ Second evaluation (soybean) } \\
\cline { 2 - 3 } \cline { 5 - 6 } Treatments & $\mathbf{R F}$ & Nem/g & & Pf & Nem/g \\
\hline Soybean BRS 133 & $72.1 \mathrm{a}$ & $1,101.3 \mathrm{a}$ & & $2,503 \mathrm{a}$ & $465.6 \mathrm{a}$ \\
Sorghum BR 800 & $49.5 \mathrm{a}$ & $324.3 \mathrm{~b}$ & & $4,034 \mathrm{a}$ & $479.6 \mathrm{a}$ \\
Kennedy ruzi grass & $5.2 \mathrm{~b}$ & $48.9 \mathrm{~cd}$ & & $954 \mathrm{ab}$ & $124.6 \mathrm{~b}$ \\
Pearl millet BRS 1501 & $5.0 \mathrm{~b}$ & $114.7 \mathrm{c}$ & & $923 \mathrm{ab}$ & $79.2 \mathrm{bc}$ \\
Pearl millet ADR 300 & $1.6 \mathrm{c}$ & $19.8 \mathrm{~d}$ & & $464 \mathrm{~b}$ & $40.0 \mathrm{c}$ \\
Showy crotalaria & $0.9 \mathrm{c}$ & $5.3 \mathrm{e}$ & & $7 \mathrm{c}$ & $0.6 \mathrm{~d}$ \\
\hline
\end{tabular}

${ }^{\mathrm{z}}$ Experiment 3 (experiment was not replicated, values are means of seven pot-replicates). Mean followed by the same letter in a column did not differ according to Tukey's test $(P=0.01)$.

Table 2. Reproductive factor $\left(\mathrm{RF}=\right.$ final population density/initial population density [Pi]) of the Brazilian populations $\mathrm{Pb}_{20}, \mathrm{~Pb}_{21}$, and $\mathrm{Pb}_{22}$ of Pratylenchus brachyurus and number of nematodes per gram of root $(\mathrm{Nem} / \mathrm{g})$ determined in the Brachiaria spp. tested 15 weeks after inoculation with $\mathrm{Pi}=270^{\mathrm{w}}$

\begin{tabular}{|c|c|c|c|c|c|c|c|c|}
\hline \multirow[b]{3}{*}{ Plants } & \multicolumn{8}{|c|}{ P. brachyurus populations } \\
\hline & \multicolumn{4}{|c|}{$\mathbf{R F}$} & \multicolumn{4}{|c|}{ Nem/g } \\
\hline & $\mathbf{P b}_{21}{ }^{\mathrm{x}}$ & $\mathbf{P b}_{20} \mathbf{x}$ & $\mathbf{P b}_{22}{ }^{\mathbf{x}}$ & Mean $^{y}$ & $\mathbf{P b}_{21}{ }^{\mathrm{x}}$ & $\mathbf{P b}_{\mathbf{2 0}} \mathbf{x}$ & $\mathbf{P b}_{22}{ }^{\mathrm{x}}$ & Mean $^{y}$ \\
\hline Palisade grass & 8.0 & 4.2 & 5.2 & $5.8 \mathrm{a}$ & 78.2 & 44.2 & 45.7 & $56.0 \mathrm{a}$ \\
\hline Kennedy ruzi grass & 3.3 & 3.7 & 3.1 & $3.4 \mathrm{~b}$ & 38.2 & 29.7 & 44.6 & $37.5 \mathrm{a}$ \\
\hline Creeping signal grass & 2.4 & 1.9 & 0.4 & $1.6 \mathrm{c}$ & 12.0 & 10.5 & 2.2 & $8.2 \mathrm{~b}$ \\
\hline Dictyoneura grass & 1.0 & 0.1 & 0.3 & $0.5 \mathrm{~cd}$ & 4.2 & 0.2 & 1.0 & $1.8 \mathrm{c}$ \\
\hline Showy crotalaria & 0.1 & 0.1 & 0.1 & $0.1 \mathrm{~d}$ & 0.2 & 0.2 & 0.0 & $0.1 \mathrm{c}$ \\
\hline Mean $^{z}$ & $3.0 \mathrm{~A}$ & $2.0 \mathrm{AB}$ & $1.8 \mathrm{~B}$ & $\ldots$ & $26.6 \mathrm{~A}$ & $17.0 \mathrm{AB}$ & $18.7 \mathrm{~B}$ & $\ldots$ \\
\hline
\end{tabular}

\footnotetext{
${ }^{\mathrm{w}}$ Experiment 2 (experiment was not replicated).

${ }^{x}$ Mean of four replicates.

y Mean of 12 replicates. Mean followed by the same letter in a column did not differ according to Tukey's test $(P=0.01)$.

${ }^{\mathrm{z}}$ Mean of 20 replicates. Mean followed by the same letter in a row did not differ according to Tukey's test $(P=0.01)$.
} 
for $P$. brachyurus. Comparing the Pf of soybean cultivated after the cover crops, the pearl millet cultivars (BRS 1501 and ADR 300) proved to be less effective in reducing $P$. brachyurus density than showy crotalaria. According to former reports $(8,22)$, P. brachyurus density decreased in two intraspecific hybrids of grain pearl millet, HGM 100 and Tif Grain 102, and in the forage cv. BN $2(\mathrm{RF}=0.4)$ but was maintained or increased in the forage $\mathrm{cv}$. BRS 1501 ( $\mathrm{RF}=1.0$ to 2.1). Growing pearl millet as a cover crop is a moderate risk for an intolerant subsequent crop in fields infested with $P$. brachyurus. Therefore, we recommend periodic evaluation of nematode densities in no-tillage fields where pearl millet is used as cover crop to determine whether the damage threshold has been exceeded.

Proso-millet, which was not tested previously for $P$. brachyurus, was rated as a poor host for this nematode in experiment 1 , similar to pearl millet. The present results about black oat cv. IPFA 99006 confirm that this cover crop is a poor host of $P$. brachyurus, as previously reported for black oat cvs. Embrapa 40 and Common (8). In Brazil, "Common" is a general denomination for combinations of heterogeneous populations of Avena strigosa. With an RF value of slightly greater than 1.0, black oat may increase densities of $P$. brachyurus; however, this grass is usually grown in cold regions of Brazil and $P$. brachyurus prefers warm temperatures.

In conclusion, although some of the graminaceous cover crops used in notillage system in Brazil are positioned as poor hosts for $P$. brachyurus, as a rule, they increase $P$. brachyurus density during long observation periods, in contrast to showy crotalaria, despite the nematode origin (population). Among the cover crops tested, dictyoneura grass, black oat, and the pearl millet cv. ADR 300 are the less suitable for $P$. brachyurus and might be used in infested fields. However, they should be not used during long periods, because they could probably increase $P$. brachyurus population density after many crop successions with susceptible hosts such as soybean, common bean, cowpea, and cotton.

\section{LITERATURE CITED}

1. Coolen, W. A., and D'Herde, C. J. 1972. A Method for the Quantitative Extraction of Nematodes from Plant Tissue. State Nematology and Entomology Research Station, Ghent.

2. Endo, B. 1959. Responses of root-lesion nematodes, Pratylenchus brachyurus and P. zeae, to various plant and soil types. Phytopathology 49:417-421.

3. Ferraz, L. C. C. B. 2006. O nematóide Pratylenchus brachyurus e a soja sob plantio direto. Rev. Plantio Direto 95:23-27.

4. Gallaher, R. N., Dickson, D. W., Corella, J. F., and Hewlett, T. E. 1988. Tillage and multiple cropping systems and population dynamics of phytoparasitic nematodes. J. Nematol. (Suppl.) 2:90-94.

5. Handoo, Z. A., and Golden, M. A. 1989. A key and diagnostic compendium to the species of the genus Pratylenchus Filipjev. J. Nematol. 21:202-218.

6. Hooper, D. J. 1986. Extraction of free-living stages from soil. Pages 5-30 in: Laboratory Methods for Work with Plant and Soil Nematodes. J. F. Southey, ed. Her Majesty's Stationery Office, London.

7. Inomoto, M. M., Machado, A. C. Z., and Antedomênico, S. R. 2007. Reação de Brachiaria spp. e Panicum maximum a Pratylenchus brachyurus. Fitopatol. Bras. 32:341-344.

8. Inomoto, M. M., Motta, L. C. C., Machado, A. C. Z., and Sazaki, C. S. S. 2006. Reação de dez coberturas vegetais a Pratylenchus brachyurus in Brazil. Nematol. Bras. 30:151-157.

9. Jenkins, W. R. 1964. A rapid centrifugalflotation technique for separating nematodes from soil. Plant Dis. Rep. 48:692.

10. Lamas, F. M. 2006. Espécies para cobertura do solo e seus efeitos no algodoeiro. Rev. Bras. Fibros. 11:55-63.

11. Machado, A. C. Z., Ferraz, L. C. C. B., and Oliveira, C. M. G. 2007. Development of a species-specific reverse primer for the molecular diagnosis of Pratylenchus brachyurus.
Nematropica 37:248-257.

12. Machado, A. C. Z., Motta, L. C. C., Siqueira, K. M. S., Ferraz, L. C. C. B., and Inomoto, M M. 2007. Host status of green manures for two isolates of Pratylenchus brachyurus in Brazil. Nematology 9:799-805.

13. Motalaote, B., Starr, J. L., Frederiksen, R. A. and Miller, F. R. 1987. Host status of and susceptibility of sorghum to Pratylenchus species. Rev. Nématol. 10:81-86.

14. Noe, J. P. 1985. Analysis and interpretation of data from nematological experiments. Pages 187-196 in: An Advanced Treatise on Meloi dogyne, Volume II: Methodology. K. R. Barker, C. C. Carter, and J. N. Sasser, eds. North Carolina State University Graphics, Raleigh.

15. Nunes, U. R., Andrade Júnior, V. C., Silva, E. B., Santos, N. F., Costa, H. A. O., and Ferreira C. A. 2006. Produção de palhada de plantas de cobertura e rendimento do feijão em plantio direto. Pesqui. Agropec. Bras. 41:943-948.

16. Riedel, R. M., Foster, J. G., and Mai, W. F. 1973. A simplified medium for monoxenic culture of Pratylenchus penetrans and Ditylenchus dipsaci. J. Nematol. 5:71-72.

17. Risso-Pascotto, C., Pagliarini, M. S., and Valle, C. B. 2006. Microsporogenesis in Brachiaria dictyoneura (Fig. \& De Not.) Stapf (Poacea: Paniceae). Genet. Mol. Res. 5:837-845.

18. Schmitt, D. P., and Barker, K. R. 1981. Damage and reproductive potentials of Pratylenchus brachyurus and $P$. penetrans on soybean. J. Nematol. 13:327-332.

19. Sharma, R. D., and Medeiros, A. C. S. 1982. Reações de alguns genótipos de sorgo sacarino aos nematóides Meloidogyne javanica e Pratylenchus brachyurus. Pesqui. Agropec. Bras. 17:697-701.

20. Silva, R. A., and Pereira, L. C. 2003. Efeito de densidades populacionais de Pratylenchus brachyurus na produtividade de duas cultivares de soja, em condições de campo. (Abstr.) Nematol. Bras. 27:268.

21. Silva, R. A., Serrano, M. A. S., Gomes, A. C., Borges, D. C., Souza, A. A., Asmus, G. L., and Inomoto, M. M. 2004. Ocorrência de Pratylenchus brachyurus e $M$. incognita na cultura do algodoeiro no estado do Mato Grosso. Fitopatol. Bras. 20:337.

22. Timper, P., and Hanna, W. W. 2005. Reproduction of Belonolaimus longicaudatus, Meloidogyne javanica, Paratrichodorus minor, and Pratylenchus brachyurus on peral millet (Pennisetum glaucum). J. Nematol. 37:214-219. 